\title{
Netnografia da reforma curricular do ensino médio brasileiro
}

\author{
Murilo Eduardo Nazário' (D) \\ Wagner dos Santos" (D) \\ Amarílio Ferreira Neto" (D)
}

\section{RESUMO}

Quais são as práticas discursivas empreendidas pelos sujeitos que têm discutido sobre a reforma do ensino médio no ciberespaço das mídias sociais? Quem são os sujeitos praticantes dessas discussões? Quais são as narrativas assumidas e difundidas no conteúdo desses discursos? Com essa investigação, almeja-se problematizar os modos como a reforma do ensino médio tem sido abordada nas redes sociais com maior número de usuários no Brasil. Desse modo, realizou-se uma netnografia nas interfaces das redes sociais, Twitter, Facebook, Instagram e YouTube utilizando como fontes as narrativas escritas, imagéticas e audiovisuais veiculadas por atores sociais que discutiram sobre a MP no 746 nesses lugares online. Os resultados sinalizam para uma disputa de narrativas e contranarrativas sociopolíticas entre direita e esquerda, demarcadas pelos próprios sujeitos, que se reverberam sobre o equacionamento dos impactos que essa reforma provocará no cotidiano dessa etapa da educação básica.

\section{PALAVRAS-CHAVE}

reforma; ensino médio; ciberespaço. 


\title{
NETNOGRAPHY OF CURRICULAR REFORM FOR BRAZILIAN HIGH SCHOOL
}

\begin{abstract}
What are the discursive practices undertaken by the subjects who have discussed the reform of high school in the cyberspace of social media? Who are the subjects practicing these discussions? What are the narratives assumed and disseminated in the content of these speeches? With this investigation, we aim to problematize the ways in which the reform of high school has been approached in social networks with the largest number of users in Brazil. Thus, a netnography was carried out on the interfaces of social networks, Twitter, Facebook, Instagram and Youtube, using as source the written, imagery and audiovisual narratives broadcast by social actors who discussed MP No. 746 in these online places. The results indicate a dispute of narratives and socio-political counter-narratives between the right and the left, demarcated by the subjects themselves, which reverberated on the equation of the impacts that this reform will cause in the daily life of this stage of basic education.
\end{abstract}

KEYWORDS

reform; high school; cyberspace.

\section{NETNOGRAFÍA DE LA REFORMA CURRICULAR DE LA ESCUELA SECUNDARIA BRASILEÑA}

\section{RESUMEN}

¿Cuáles son las prácticas discursivas emprendidas por los sujetos que han discutido la reforma de la escuela secundaria en el ciberespacio de las redes sociales? ¿Quiénes son los sujetos que practican estas discusiones? ¿Cuáles son las narraciones asumidas y difundidas en el contenido de estos discursos? Con esta investigación, nuestro objetivo es problematizar las formas en que se ha abordado la reforma de la escuela secundaria en las redes sociales con el mayor número de usuarios en Brasil. Así, se realizó una netnografía en las interfaces de las redes sociales, Twitter, Facebook, Instagram y Youtube, utilizando como fuente las narraciones escritas, de imágenes y audiovisuales transmitidas por actores sociales que discutieron el MP No.746 en estos sitios en línea. Los resultados apuntan a una disputa de narrativas y contra-narrativas sociopolíticas entre la derecha y la izquierda, demarcadas por los propios sujetos, que repercutieron en la ecuación de los impactos que esta reforma causará en la vida cotidiana de esta etapa de la educación básica.

PALABRAS CLAVE

reforma; preparatoria; ciberespacio. 


\section{INTRODUÇÃO}

Em 22 de setembro de 2016, o então ministro da Educação envia ao Congresso Nacional, por meio da Medida Provisória no 746, um plano de reforma do ensino médio brasileiro. Nessa versão, os componentes curriculares seriam reorganizados e distribuídos em itinerários formativos, a saber: linguagens e suas tecnologias; ciências da natureza e suas tecnologias; matemática e suas tecnologias; ciências humanas e sociais aplicadas; e formação técnica e profissional. Com isso, a partir de um ano e meio cursado, os alunos escolheriam um desses itinerários para concluir o ensino médio.

Todavia o texto final, que alterou a LDB no 9.394/1996 (Brasil, 2017b) e colaborou na subtração das Diretrizes Curriculares Nacionais da Educação Básica (DCNS), carece de orientação sobre as principais questões no que se refere à estrutura, à oferta e ao compartilhamento dos componentes curriculares a serem disponibilizados em um dos cinco itinerários formativos. Algumas dessas questões ficaram a cargo das definições estabelecidas com a implantação da Base Nacional Curricular Comum (BNCC) ${ }^{1}$.

Essas alterações desencadearam uma série de manifestações, quase instantâneas, de entidades, tais como: a Associação Nacional de Pós-Graduação e Pesquisa em Educação (Anped) em 23 de setembro; a Associação Nacional de História (Anpuh) em 26 de setembro; e o Conselho Nacional de Educação Física (Confef) em 28 de setembro.

Paralelamente, as principais mídias sociais brasileiras "quebraram a internet" com diferentes postagens que se referiam a essas alterações, seja por textos curtos via \# ${ }^{3}$ vinculados ao www.twitter.com.br, seja via imagem, como no www.instagram. com e por vídeos postados no www.youtube.com, seja por meio da junção dos três signos: textos, vídeos e imagens, como no www.facebook.com. Elementos que chamam a atenção pela representação que essas mídias possuem no contexto social brasileiro. Um dos dados dessa condição refere-se ao número de usuários que elas possuem no Brasil: o Facebook tem hoje 129 milhões de usuários; o Instagram, 35 milhões; o Twitter, 33,3 milhões; e o YouTube, 82 milhões (Ribeiro, 2019). Esses números fazem dessas mídias extensões e cotidianos próprios, inclusive para discutir a reforma do ensino médio, constituindo-se como lugares emergentes de difusão e

1 A última versão entregue pelo Ministério da Educação e Cultura (MEC), em abril de 2018, apresentou maiores estruturas em relação aos direcionamentos para as áreas de Matemática e Linguagens, em específico o componente curricular Língua Portuguesa. Com isso, as demais áreas e seus respectivos componentes curriculares ainda terão de esperar as elaborações dos currículos das demais instâncias de educação.

2 Gíria utilizada pelos internautas para descrever uma movimentação interna mediante compartilhamentos, curtidas e comentários intensos na internet sobre um mesmo assunto.

3 Hashtag é um composto de palavras-chave, ou de uma única palavra, precedido pelo símbolo cerquilha (\#). Tags significam etiquetas e referem-se a palavras relevantes que, associadas ao símbolo \#, se tornam hashtags. Esse tipo de marcação, utilizada nas redes sociais e em outros meios, serve para associar uma informação a um tópico ou discussão. Geralmente, as hashtags se tornam links indexáveis pelos mecanismos de busca (Redação, 2016). 
compartilhamento de informações, ideias, perspectivas e possíveis campos de pesquisa, que mantêm atualizada e reatualizada a discussão em torno dessas mudanças.

Elas forneceram visibilidade a questionamentos e reflexões dos praticantes do cotidiano escolar, uma vez que, entre os diferentes usos e consumos (Certeau, 2002), as mídias podem ser consideradas ferramentas de difusão e compartilhamento de ideias, opiniões, fatos, dados, críticas, frustrações e perspectivas. Ainda, evocam uma dupla compreensão do espaço e tempo cotidianos: a primeira apresenta-se como extensão do lugar praticado e a segunda como lugar próprio a ser praticado. $\mathrm{Ou}$ seja, elas recebem componentes narrativos cujos valores são de sintaxes espaciais, as quais indicam um processo configurativo estabelecido por conexões e relações sociais, expressas por trocas constantes, migrações, deslocamentos e trânsitos de um espaço ou de um lugar para outro.

A internet constitui-se como lugar que se estende em um movimento de interconexão, não existindo mais a relação real e virtual, mas apenas um lugar. Para Levy (1999, p. 47), "o virtual na ótica filosófica é toda entidade desterritorializada capaz de gerar diversas manifestações concretas em diferentes momentos e locais determinados, sem, contudo, estar ela mesma presa a um lugar ou tempo em particular".

No caso das mídias sociais como experiências desse virtual, elas podem ser também compreendidas como interfaces, que possibilitam a interação por textos, sons, imagens, vídeos e mesmo a leitura, e permitem a máxima ligação do mundo ordinário com o mundo virtual (Levy, 1999). Já Poissant (2009) considera que uma das estruturas fundamentais das interfaces é possibilitar a transfiguração do sujeito espectador para ator, conectando homens e máquinas. Para isso, a autora usa o termo artes-mídias, que transforma as interfaces em tipos condutores e modificadores dos fazeres cotidianos, com menções a uma possível estética artística, em que pessoas podem ser escritores, colunistas, artistas, pintores, cineastas e músicos.

Desse modo, quais são as práticas discursivas empreendidas pelos sujeitos que têm discutido sobre a reforma do ensino médio no ciberespaço das mídias sociais? Quem são os sujeitos praticantes dessas discussões? Quais são as narrativas assumidas e difundidas no conteúdo desses discursos? Com essa investigação, almeja-se problematizar os modos como a reforma do ensino médio tem sido abordada nas redes sociais com maior número de usuários no Brasil.

\section{MÉTODOS}

O espaço virtual, ou ciberespaço, tem-se constituído como lugar de possibilidades ímpares para a realização de novas etnografias, seja investigando grupos específicos que participam de blogs, seja passando pelas redes sociais até alcançar sites específicos sobre uma determinada temática.

Para Aguiar (2007, p. 4), “a etnografia digital ou online, compreende a observação dos sujeitos em seu processo de construção de percepções e comportamentos na relação social em rede". Essa vertente metodológica começou a ser explorada desde o surgimento de comunidades virtuais, no fim dos anos 1980. 
A transposição dessa metodologia para o estudo de práticas comunicacionais mediadas por computador recebe o nome de Netnografia, ou etnografia virtual e sua adoção é validada no campo da comunicação pelo fato de que muitos objetos de estudo localizam-se no ciberespaço. (Montardo e Rocha, 2005, p. 1)

Entretanto, interessa que definitivamente se trata de um envolvimento científico muito peculiar, à medida que é possível para o (a) pesquisador (a) tornar-se invisível, ou seja, ver sem ser visto (a), não interferindo, em princípio, na dinâmica da interação observada. É essa participação (mesmo que invisível) no grupo que pode viabilizar a apreensão de aspectos daquela cultura, possibilitando a elaboração posterior de uma descrição densa, que demanda uma compreensão detalhada dos significados compartilhados por seus membros e da rede de significação em questão (Braga, 2006).

Nesse sentido, Kozinets (2014) sugere quatro ações práticas que podem recuperar procedimentos básicos de metodologia específicos da transposição da etnografia para a netnografia: entrée cultural, coleta e análise dos dados, ética de pesquisa e checagem de informações com os membros do grupo.

Desse modo, realizou-se uma netnografia nas interfaces das redes sociais $\mathrm{Fa}$ cebook, Instagram, Twitter e Youtube, utilizando como fonte as narrativas (textuais, imagéticas ou audiovisuais) veiculadas por atores sociais brasileiros que discutiram e/ou se manifestaram sobre a Medida Provisória (MP) no 746 nesses lugares online. Diante das particularidades que envolviam cada um dos sites e as suas produções materiais, bem como o recomendado pela netnografia, foi necessário estabelecer alguns critérios de exclusão e seleção: o primeiro refere-se à clareza em torno da formulação da questão de pesquisa, pois seria inviável analisar tudo que foi postado ao longo do tempo sobre o ensino médio. Por isso o deslocamento para a reforma dessa etapa, que além de sua marcação histórica, apresentaria um volume menor de dados e traria outras informações sobre essa fase da escolarização. O segundo elemento diz respeito à abrangência temporal de incursão do pesquisador no campo. Para tanto, consideramos apenas as postagens realizadas desde 22 de setembro de 2016, data de emissão da MP/746, até 16 de fevereiro de 2017, data do sancionamento da Lei 13.415. O terceiro elemento refere-se ao entrée cultural, para o qual foi criada uma conta em cada uma das redes selecionadas, como pode ser visto na Figura 1.

Sequencialmente foram inseridos os descritores mp ensino médio, \#ensinomedio, \#reformaensinomedio e reformaensinomedio nas ferramentas de busca existentes em cada uma das redes sociais, conforme exemplo da Figura 2.

Em seguida, mediante as recomendações de Kozinets (2014), foi realizado o processo de observação e armazenamento documental, mantendo o recorte temporal compreendido entre os dias 23 de setembro de 2016 e 16 de fevereiro de 2017. Como as discussões e participações dos membros giravam em torno da medida provisória, optamos por não formular entrevistas ou mesmo temas geradores de discussão por meio de novas postagens, mas sim analisar o material já produzido, denominados dados arquivais. Assim, manteve-se acompanhamento diário e extensivo de quase 5 horas observando as discussões e interações dos participantes nas redes sociais analisadas. Vale ressaltar que todas as páginas, a partir da criação de um login, não precisavam de pré-requisitos cadastrais ou autorização para acesso às informações, 


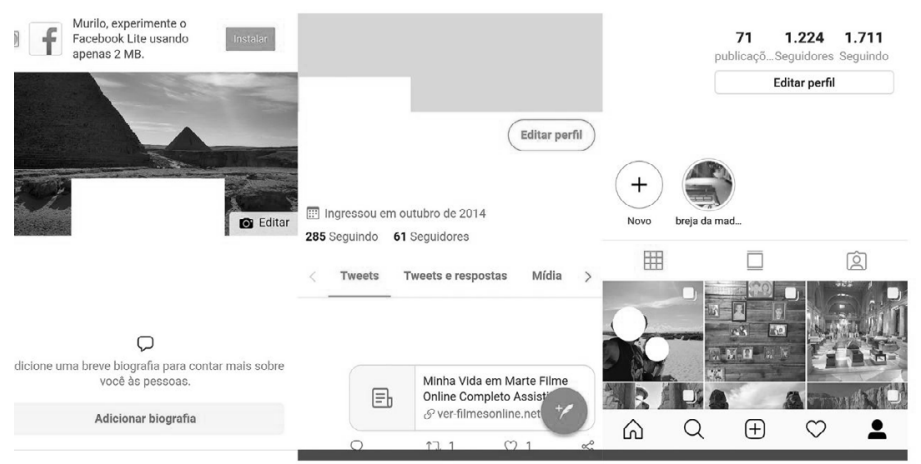

Figura 1 - Contas criadas para ingresso e interação nas plataformas de 3 mídias sociais.

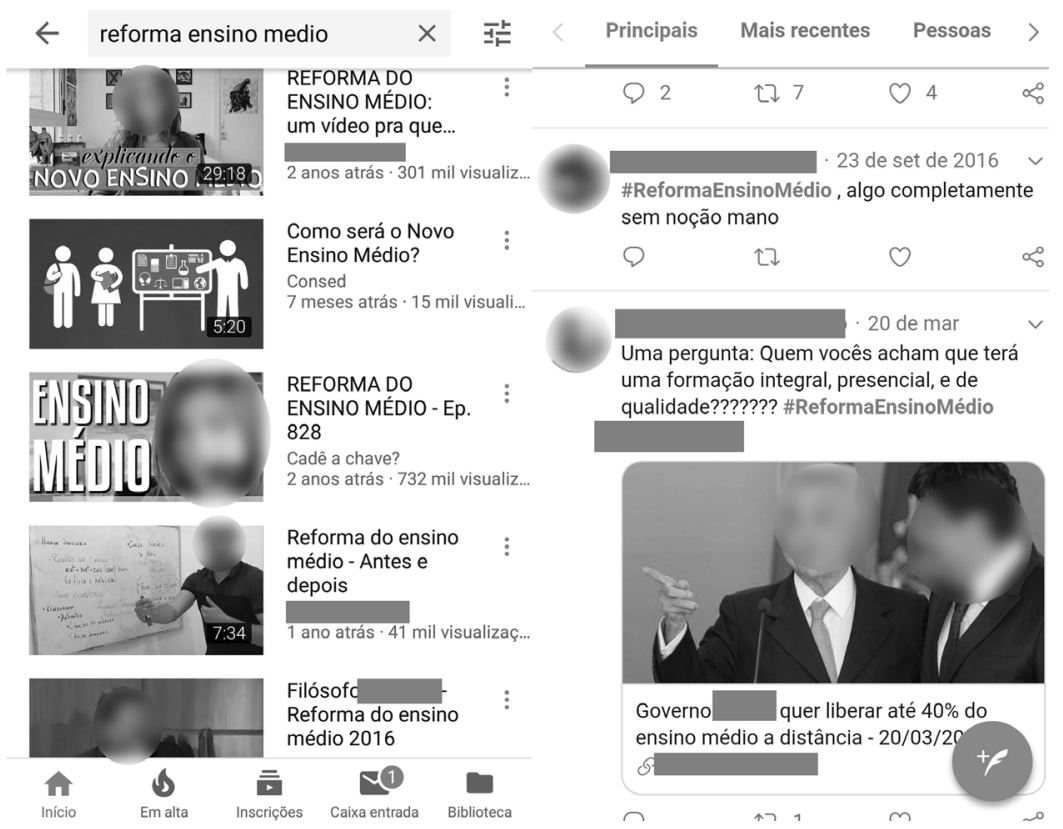

Figura 2 - Exemplo da template de busca e parte dos resultados gerados via descritores no YouTube.

comentários e postagens. Com isso, analisava-se, de acordo com cada uma das redes sociais, interações como as da Figura 3.

$\mathrm{Na}$ rede social Twitter, as pessoas podem interagir produzindo um twit inicial, que por sua vez possibilita a interação de outros usuários, seja curtindo, conforme figura do coração, retweetando (replicando) com base na figura de centro, ou podem participar tecendo comentários conforme figura do balãozinho. Vale dizer que, cada uma das plataformas analisadas possui interfaces próprias que otimizam esse tipo de comunicação intragrupal, mas mantêm esse pressuposto básico de postagem inicial, 
TWITEIRA

O Plenário da Câmara concluiu a votação da reforma do ensino médio (MP 746). Desde que o... fb.me/7qSliuwGC

Q 1 饯 1

Fonte: extraída do Twitter.

Figura 3 - Modelo de interação dos participantes, exemplo do Twitter.

seja por vídeo (YouTube), imagem (Instagram), combinação textual e imagética (Facebook) e demais participações interativas dos outros membros.

A fase seguinte foi dedicada às análises e interpretações interativas do material coletado. Para Kozinets (2014), o pesquisador deve esforçar-se para compreender as participações dos membros em articulação com um contexto de discussão. Nesse caso, a opção pela seleção dos dados arquivados colabora para manter a autoria e intenções subjetivas produzidas pelos sujeitos dessas redes. Outro elemento importante que é considerado nas etnografias refere-se à fidedignidade de comportamentos e ações do pesquisado diante do pesquisador, condição que não ocorreu, pois as fontes foram produzidas não por indução do pesquisador, e sim pelas representações e interesses dos participantes dessas mídias sociais.

A partir das especificidades dispostas nas interfaces interativas de cada rede social, iniciou-se o processo de leitura e captura integral das narrativas produzidas. Para tanto, em cada uma das páginas analisadas, convertia-se o conteúdo textual em Portable Document Format (PDF), conforme Figura 4, para otimizar o processo de análise.

Ação que forneceu o seguinte quantitativo por página: Instagram, com \#reformaensinomedio deu origem a 50 páginas com uma postagem cada uma; Facebook, com a \#reformadoensinomédio gerou 15 páginas com 3 a 4 postagens por página, já com \#reformaensinomédio foram produzidas 28 páginas com 3 a 4 postagens; Twitter, com a \#mpensinomédio resultou em 5 páginas com 7 a 8 postagens por página e com a \#reformaensinomédio, 4 páginas com 7 a 8 postagens por página. Em relação ao Youtube, procedeu-se de modo diferente: inicialmente selecionou-se os vídeos com maior número de visualizações e, depois de analisados, foram extraídos de cada um os comentários produzidos, fornecendo cerca de 20 páginas com 10 a 12 postagens por página.

Kozinets (2010) sinaliza que, diante do volume extenso do material textual coletado, o pesquisador faça uso de softwares de análise qualitativa para reconhecimento e organização semântica. Nessa perspectiva, utilizou-se o Iramuteq R, sendo inserido, na interface do software, todo o material coletado, procedimento que produziu uma nuvem de palavras ${ }^{4}$ e um grafo de similitude ${ }^{5}$ compostos pelos elementos textuais de maior recorrência nas plataformas pesquisadas. Essa pesquisa foi aprovada pelo Comitê de Ética em Pesquisa da UFES, CAAE $n^{\circ}$ 78655917.2.0000.5542 e Parecer n.o 2.364.717.

4 Análise léxica que ocorre a partir do agrupamento e organização das palavras em função da sua frequência (Camargo e Justo, 2013).

5 É um tipo de análise que baseia-se na teoria dos grafo que possibilita a identificação das coocorrências entre palavras e suas possíveis conexões (Camargo e Justo, 2013). 


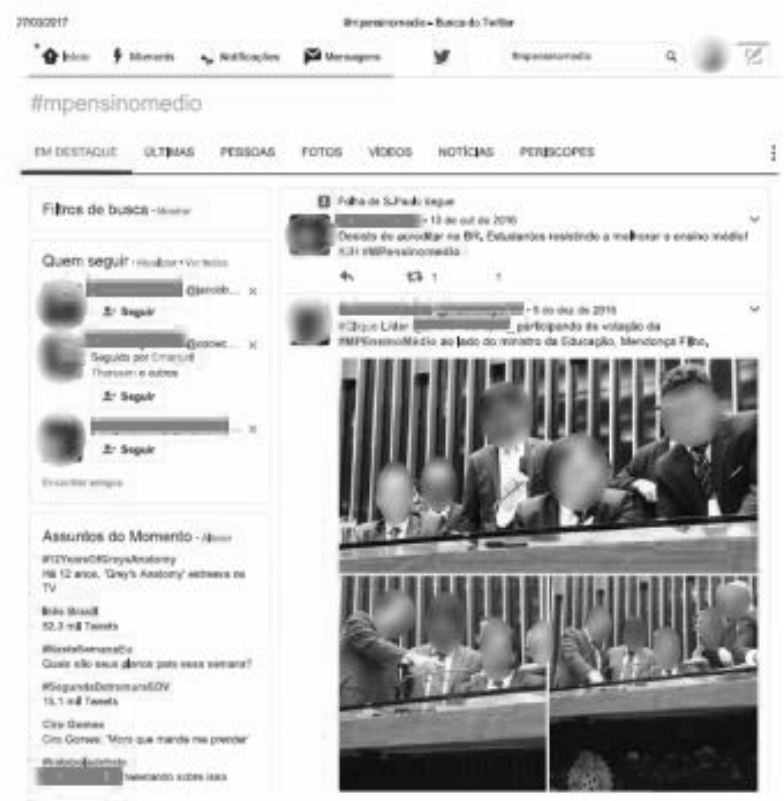

Figura 4 - Exemplo de imagem convertida da plataforma virtual para PDF.

\section{ANÁLISE E DISCUSSÃO DOS RESULTADOS}

Para ampliar o procedimento de análise, foram extraídos fragmentos textuais completos das interações produzidas pelos sujeitos nas mídias sociais, com o intuito de situar as palavras produzidas pelo software, conforme a Figura 5, no contexto das narrativas integrais desenvolvidas pelos participantes. Como critério de seleção, optou-se por aquelas que possuíam maior número de comentários ou curtidas, que geralmente se situavam nas primeiras páginas das plataformas, uma vez que:

A netnografia observa não apenas as palavras usadas em interações sociais, mas também os elementos do fórum, as características do comunicador, as linguagens empregadas, a história, o significado, o tipo de interação. Ela examina fontes, espaçamento, símbolos, textos, imagens, fotos e vídeos. (Kozinets, 2010, p. 6)

Segundo Kozinets (2010, 2014), faz-se significativo articular as ações dos sujeitos em um determinado contexto, principalmente para situar os sentidos expressos nas narrativas textuais produzidas. Nessa perspectiva, foi realizado o procedimento de extração dos vocábulos produzidos pela nuvem de palavras. A grafia textual presente nos vocábulos assume mais sentido quando é articulada com seu intertexto. Para tanto, elaborou-se o grafo de similitude, conforme o IramuteqR, representado pela Figura 6. 


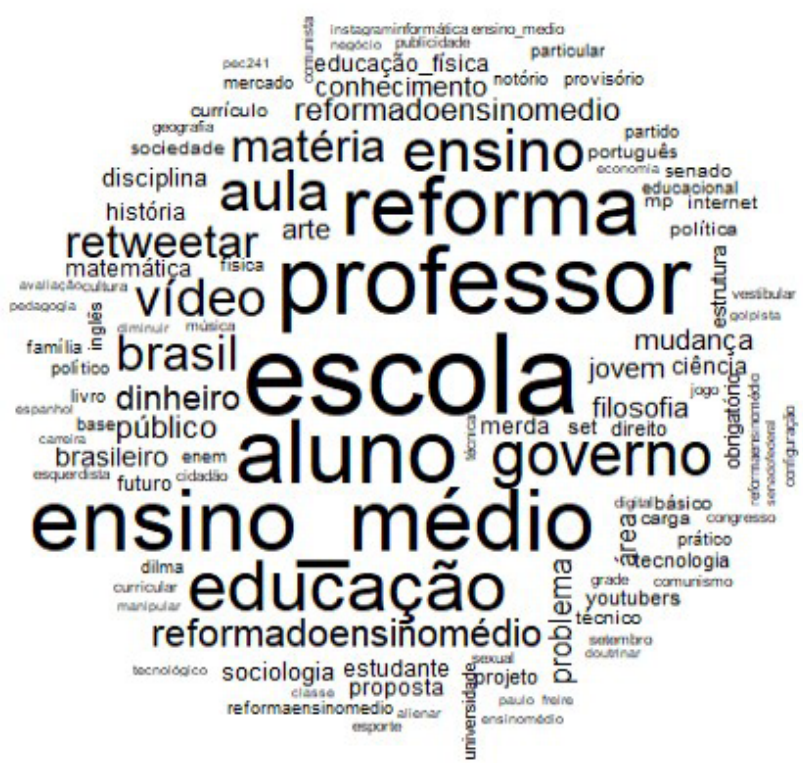

Figura 5 - Nuvem de palavras a partir da recorrência por vocábulo do Iramuteq $\mathbf{R}$.

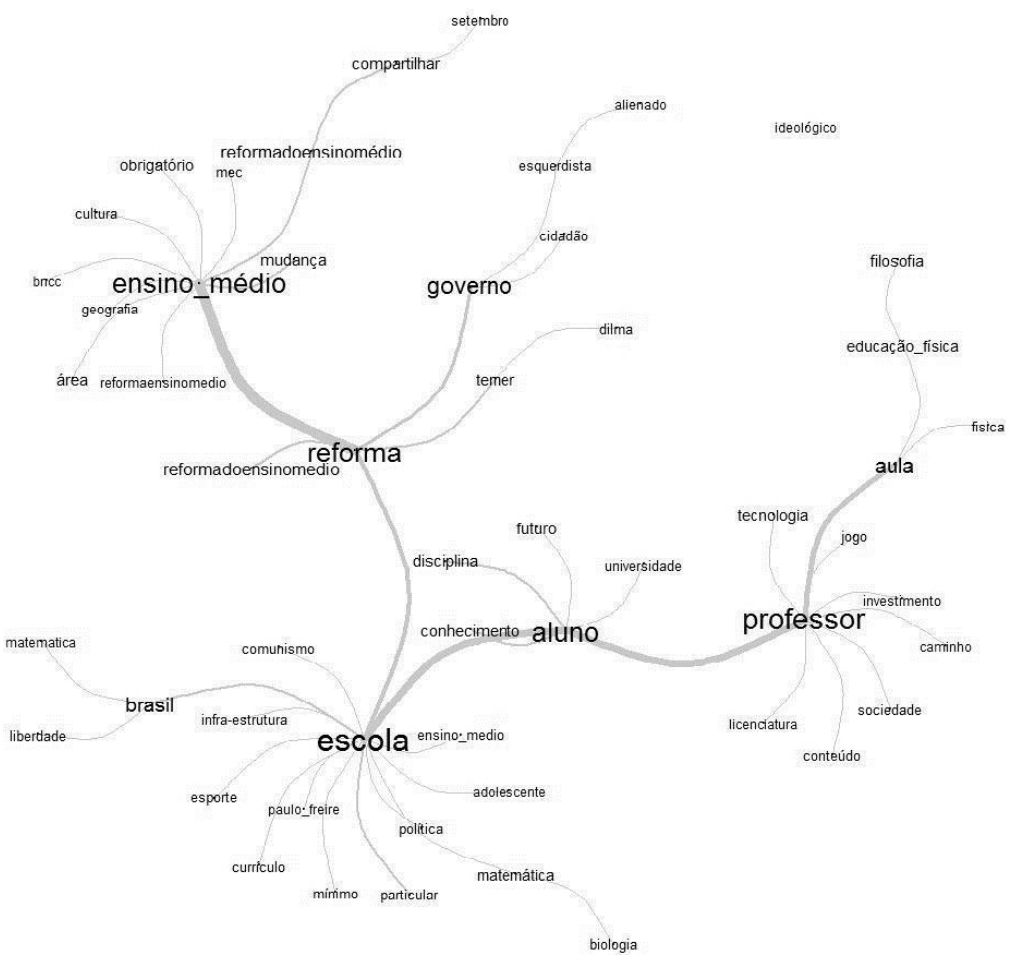

Figura 6 - Grafo de similitude da relação entre os vocábulos e o contexto narrativo. 
Tanto na nuvem de palavras quanto no grafo de similitude, os vocábulos ensino médio, reforma, governo, escola, professor e aluno expressam e representam a questão central que envolve as mudanças nessa etapa de ensino. Ao empreender um movimento de análise dos grifos da direita para a esquerda, trazendo os elementos semânticos que circundam os vocábulos principais na Figura 6, podem-se averiguar os sentidos sociopolíticos que incidem sobre os desdobramentos dos rearranjos curriculares para as escolas de ensino médio.

Dadas as particularidades dessas fontes e os atores que as produziram, é possível compreender que essa reforma fez do ensino médio um objeto histórico em movimento. Para Bloch (2001) praticar a pesquisa histórica é ir além das armadilhas do tempo, por vezes representado de modo cronológico pelas expressões passado e presente. Diante disso, infere-se que o ensino médio no contexto atual, assume a condição de continuum, ou seja, está disposto de modo diacrônico no entrelugar temporal.

Dessa forma, diante daquilo que as fontes sinalizavam no período de observação acrescidas das pistas e indícios (Ginzburg, 2002) deixados nas Figuras 5 e 6, os resultados foram organizados em duas categorias:

- indícios sociopolíticos do ensino médio no contexto online;

- atores sociais no lugar online.

\section{INDÍCIOS SOCIOPOLÍTICOS DO ENSINO MÉDIO NO CONTEXTO ONLINE}

Um dos pontos centrais da reforma que foram observados relaciona-se com os sentidos sobre as finalidades ${ }^{6}$ atribuídas a essa etapa da educação básica. A todo momento os sujeitos discutiam, por vezes comparando, os modelos e os lugares que o ensino médio tem ocupado no Brasil com o que foi proposto nessa medida provisória. Elementos que podem ser exemplificados, em alguns dos fragmentos textuais coletados.

Twitteiro 10: concordo desse jeito o pobre não têm que ficar ocupando um lugar na faculdade só por causa de cotas.

Twitteiro 13: "\#NovoEnsinoMédio quer formar gente pro mercado. Saber pensar e ter senso crítico não precisa não. Literalmente um não pense, trabalhe".

Youtube 03: A questão é, o novo ensino médio não apresenta essa função de contextualizar o aluno com o mundo a sua volta (sempre achei isso importante e apliquei em minhas aulas).

Youtuber 17: Termina o ensino médio ponto pra trabalhar mercado para os pobres, vestibular para os ricos!

6 Etimologicamente, finalidade tem a ver com um fim a ser alcançado. No presente caso, compreende-se que seriam as aprendizagens (re)apropriadas pelos alunos ao término do ensino médio. Cuja responsabilidade seria do Estado e das políticas públicas educacionais. 
Youtube 18: no meu vestibular só vai ter as matérias que eu escolhi estudar no ensino médio também? rsrsrsrsrs.

Instagranzeiro 11: Esse projeto é maravilhoso, vai incentiva mais os jovens em suas carreiras futuras e diminuir a evasão escolar, gente oq mais tem é aluno gasiando aula chata pq $n$ interessa para a vida, mais imagina ele fazer só a a matérias que vão ajudar na sua vida, vai ser mais aluno na escola que nas ruas propenso ao tráfico e sem falar que a revolta dos professores mostra o despreparo deles.

Para Kuenzer (2000), os pressupostos que têm contribuído para que essa fase de ensino seja recolada constantemente no centro das discussões sobre a educação básica estão relacionados com suas finalidades no projeto de escolarização brasileiro, alternando historicamente entre: oferecer um ensino profissionalizante com caráter de terminalidade ou oferecer um ensino propedêutico voltado ao prosseguimento dos estudos em nível superior, cabendo, ainda, nessa segunda categoria, a possibilidade de segmentação em razão da área de curso superior que o aluno pretende seguir.

Dessa forma,

Ao longo da história, o ensino médio se constituiu numa ausência socialmente construída, de um lado, pela não preocupação com as bases da ampliação da produção científica, técnica e tecnológica e de outro pela destinação de amplo segmento da população à opção da formação dominantemente para o trabalho simples. Assim, tanto quantitativa como qualitativamente, o ensino médio não se constituiu como estratégia de desenvolvimento e como etapa indispensável na formação e desenvolvimento da maioria da população jovem. (Brasil, 2013, p. 3)

Esses arquétipos estruturais do ensino médio podem ser mais bem entendidos com base na análise sobre as mudanças históricas, políticas e ideológicas sucedidas na sociedade do trabalho. A concepção de trabalho modificou-se com a lógica do capital e com ela houve reverberações para as concepções ideológicas de educação, tornando essa estrutura uma prática social mediadora do processo de produção, político, ideológico e cultural. Sendo assim, como etapa final da educação básica, o ensino médio passa a ser configurado estrategicamente na relação entre trabalho, cultura e conhecimento científico, para atender aos ditames socioeconômicos cujos princípios do ato educativo assumem estruturas ético-políticas e não técnico-didáticas ou metodológicas de aprendizagem (Frigotto, 2012).

As possíveis mudanças a serem realizadas no ensino médio brasileiro ficaram centradas à dimensão do reordenamento curricular e a cargo dos órgãos governamentais. E esses, ao estabelecer os caminhos a serem tomados pela educação brasileira, têm optado, em maior ou menor grau, pela vertente da educação no viés neoliberal. Sustenta esse exposto, Moreira (2000, p. 109):

Em numerosos estudos, têm-se criticado as recentes reformas educativas promovidas em grande parte do mundo, nas quais assumem relevo os esforços por reformular os currículos dos distintos graus de ensino. Utilizando variados 
referenciais teóricos, as análises alertam, dentre outros aspectos, para o fato de que as propostas se inserem em um movimento universal destinado a reestruturar os sistemas educativos das sociedades ocidentais do bem-estar (Carlgren 1998), desempenham importante papel nos processos de legitimação que ocorrem nessas sociedades (Popkewitz, Pitman e Barry 1998), expressam os interesses conservadores de grupos de direita que procuram aplicar às escolas as leis do livre mercado (Apple 1993; Whitty, Power e Halpin 1998) e se concretizam em práticas globais cujas implicações são produzir sistemas de inclusão e de exclusão (Burbules 1998). Acentuam, também, que as mudanças curriculares costumam ser acompanhadas de tentativas de implantação de um sistema nacional de avaliação e de alteração dos arranjos pelos quais se formam e se aperfeiçoam os docentes.

Reafirmando um dos sentidos das etnografias, é preciso situar as composições textuais, imagéticas e audiovisuais produzidas por essas mídias sociais no cenário sociopolítico educacional mais amplo. Uma das maneiras de realizar esse movimento é utilizar os registros contidos nos documentos oficiais, visto que essas fontes constituem lugares manipuláveis de poder repletos de vontades de "fazer crer político" (Certeau, 2002), em que a instância escolar é difundida como ideias veiculadas.

Nos Parâmetros Curriculares Nacionais para o Ensino Médio (Brasil,2000), é possível extrair indícios que consideram a necessidade de articular o conhecimento escolarizado com as transformações transcorridas na sociedade contemporânea, com destaque para as consequências do avanço tecnológico. Por isso, essa etapa deveria assegurar aos seus alunos, na condição de etapa final da educação básica, competências que lhes permitissem produzir conhecimento, viver plenamente seus cotidianos sociais e participar do mundo do trabalho. Dessa maneira, os componentes curriculares foram organizados em áreas as quais os objetos de estudo tivessem aproximação. A intenção era que possibilitasse ao educando a aquisição de um conhecimento de bases científicas em suas diversidades epistêmicas, da Matemática às Ciências Humanas.

Já na elaboração das DCNs (Brasil, 2013) 7 , as finalidades do ensino médio são definidas de acordo com os princípios do trabalho, ciência, tecnologia e cultura, no intuito de assegurar uma formação humana ampla. Para isso, o conhecimento relacionado com o trabalho deveria remeter à perspectiva de formação e desenvolvimento dos indivíduos, inerentes da transformação humana sobre a natureza, como o elemento básico para os demais elementos. Os aspectos tecnológicos e científicos referem-se à intervenção humana sobre o meio material, isto é, projetar

7 Documento produzido em 2013 e que torna-se praticamente refutado com a criação da BNCC que subsidiará os rumos dessa reforma. Vale dizer que o espaço temporal que separa ambos documentos refere-se a três anos, aspectos que levantam as seguintes reflexões, houve tempo para o documento de 2013 tornar-se ultrapassado? Quem são os atores sociais incumbidos da produção de um e outro? Quais continuidades e descontinuidades serão realizadas? Elementos que possuem em sua égide as reconfigurações políticas que se estabeleceram no Brasil nos últimos anos. 
e produzir formas de conhecimentos que contribuam para as suas atividades vitais individual e coletiva que estruturam a realidade. A cultura é entendida como a atividade humana que articula um conjunto de representações, símbolos, expressões materiais e modos dinâmicos de socialização que constituem o modo de vida de uma população determinada. Essa etapa e seus componentes curriculares deveriam assegurar tais saberes.

Entre as narrativas, notam-se aquelas que incidem sobre as limitações que essa reforma apresenta. Uma delas considera que as modificações sobre a composição curricular não são suficientes para o desenvolvimento do ensino médio, pois é preciso que se realize, de modo articulado, outras ações desde as melhorias estruturais nas escolas, passando pelo equacionamento das diferenças sociais e econômicas que incidem de modo direto no acesso, permanência e continuidade escolar. Como pode ser mais bem analisado:

Youtuber 19: Esse vídeo foi pouco imparcial, pois só falou como fosse algo bom, de fato o projeto é ótimo, tanto que países de alto indice de educação (como a Coréia do Sul) fizeram essa reforma. Entretanto demorou mais de quarenta anos, não estou dizendo que precisa mais de uma década, mas um ano é muito pouco, muito mais com um país sem uma boa base escolar.

Youtuber 20: A reforma do Ensino Médio deveria vim JUNTO COM UMA REFORMA NAS ESCOLAS, porque ninguém vai querer ficar SENTADO numa cadeira DURA por mais TEMPO além do CALOR QUE FAZ NA SALA E UM MATERLAL RUIM.

Twiiteiro 10: Sobre o \#novoensinomédio, as escolas nem estruturas físicas têm, dai resolvem mudar o ensino. Ao invés de melhorar outras coisas.

Youtuber 07: O que eu acho é que a escola deveria servir mais como uma preparação para a vida de um modo geral, ao invés de ensinar coisas como Baskara e trigonometria, que dificilmente alguém vai utilizar após concluir o EM.

Youtuber 05: Ok, que o curriculo possa e deva ser melhorado. Mas, terá pouco efeito em escolas sucateadas e professores fu... e mal pagos! Falam no uso das tecnologias, quando nem espaço físico ou virtual é disponibilizado. Antes de mexer no currículo, deveria-se disponibilizar acesso rápido, barato e para grande volume de dados, para TODAS as pessoas.

No que se refere à representação de currículo, Sacristán (2000) o considera como um entrecruzamento do cultural e do pedagógico, cuja função é ser práxis equilibrada da ação educativa que envolve interesses e forças, afirmações, conflitos, contraposições, papéis predefinidos e em movimento, que gravitam sobre o sistema educativo. Ao realizar o movimento de análise desse processo de composição curricular, deve-se ir além das perspectivas centradas na seleção e oferta de conteúdos: compreender como os códigos e práticas se fazem componentes essenciais. Os códigos assumem a função de ser elementos que provêm de opções políticas, sociais, epistemológicas, princípios pedagógicos ou psicológicos e critérios organizacionais que intervêm na seleção, ordenação, sequência e instrumentalização pedagógica dos currículos aos professores e alunos (Sacristán, 2000). 
Assim,

O currículo é uma práxis antes que um objeto estático emanado de um modelo coerente de pensar a educação ou as aprendizagens necessárias das crianças e dos jovens, que tampouco se esgota na parte explícita do projeto de socialização cultural nas escolas. É uma prática, expressão, da função socializadora e cultural que determinada instituição tem, que reagrupa em torno dele uma série de subsistemas ou práticas diversas, entre as quais se encontra a prática pedagógica desenvolvida em instituições escolares que comumente chamamos ensino. $\mathrm{E}$ uma prática que se expressa em comportamentos práticos diversos. $\mathrm{O}$ currículo, como projeto baseado num plano construído e ordenado, relaciona a conexão entre determinados princípios e uma realização dos mesmos, algo que se há de comprovar e que nessa expressão prática concretiza seu valor. Uma prática na qual se estabelece um diálogo, por assim dizer, entre agentes sociais, elementos técnicos, alunos que reagem frente a ele, professores que o modelam, etc. (Sacristán, 2000, p. 15-16)

O currículo não é um reservatório de saberes estáticos, mas um território de disputa de saberes na pluralidade epistemológica do mundo atual e na heterogeneidade de sujeitos sociais que chegam às escolas. Pensar em outros currículos exige reconhecer essa pluralidade de saberes, de conhecimentos, reconhecer a pluralidade epistemológica do nosso mundo e especificamente a pluralidade epistemológica e cultural que chega às escolas com os outros mestres e educandos.

Para Krawczyk (2009) e Kuenzer (2000), o currículo do ensino médio sempre foi um campo de disputa entre diferentes projetos sociais e grupos profissionais, seja pelo concurso de uma parcela do conhecimento socialmente produzido, seja pelo potencial de ampliação da inserção no mercado de trabalho. $\mathrm{O}$ argumento utilizado por uma parcela que defende a retirada de tais componentes ocorre porque os considera de pouca utilidade para as características e cobranças do atual mercado de trabalho.

Ademais, no contexto das interações e produções dos sujeitos nessas mídias, é possível averiguar que a relação entre finalidades e currículo do ensino médio estão atreladas, constantemente, aos saberes disciplinares. Os sujeitos da pesquisa consideram que essas estruturas são responsáveis por fornecer aos estudantes conhecimentos imprescindíveis para praticarem os seus cotidianos. Assim, um grupo considera que ao impedir o acesso do aluno a algum dos componentes curriculares, dos 13 que hoje compõem o ensino médio, essa reforma produzirá retrocessos, tais como o impedimento ao conhecimento plural que as áreas de conhecimento que sustentam essas disciplinas apresentam.

Conforme pode ser averiguado nas transcrições:

Youtuber 29: Esse MP é uma tentativa de sucatear ainda mais a educação. Como bem explicado no vídeo, não somos, Portugal, Alemanha e tal, sem contar que nossas escolas pecam muito em infraestrutura. 
Twitteiro14: Essa reforma do ensino médio não faz sentido! Educação Física deveria ser opcional, História e Geografia obrigatórios.

Youtuber 42: eu não concordo com tirar a obrigatoriedade de nenhuma dessas disciplinas, primeiro, porque a carga horaria delas sempre foram pequenas, como de fato devem ser. O que faz com que elas estejam defasadas e não sejam interessantes para os alunos, é não serem abordadas por professores capacitados, o que vai apenas piorar com a MP já que a partir de agora, o professor só precisará ter "notório saber", e não mais uma especialização na área.

Youtuber 23: As crianças não irão saber como devem tratar esses assuntos se não forem educados desde cedo. Porque acha que pessoas um pouco mais velhas têm uma visão tão homofóbica e um tanto quanto machista?

Youtuber 25: Eu conclui o Ensino Médio sem saber a tal fórmula de Baskara. (Sim ela foi ensinada, mas ' $E U$ ' não aprendi)... No entanto isso não me atrapalhou em nada, os clientes que sirvo no McDonalds nem se importam com isso.

Instagranzeiro 2: sobre. arte, eu acho desnecessário, prefiro aula de música, ou laboratórios de informática, ou uma aula de inglês com professores americanos, esse inglesinho que se ensina na escola é uma puta bosta....\#minhaopiniao.

Nessa perspectiva do tipo de conhecimento que seria relevante e irrelevante nessa etapa de ensino, mediante essa flexibilização curricular, é possível compreender as razões da possibilidade de perda da obrigatoriedade dos componentes curriculares Educação Física, Artes, Filosofia e Sociologia e a afirmação da obrigatoriedade de Matemática, Língua Portuguesa e Língua Estrangeira.

Outra mudança estrutural que está relacionada com a organização curricular abrange o aumento gradativo da carga horária, com o objetivo de ampliar a oferta do ensino médio integral. Sobre essa questão, desde as DCNS de 2013 até as proposições na LDB, versão com alterações da Lei no 13.415 em 2017, têm-se:

II - No Ensino Médio regular, a duração mínima é de três anos, com carga horária mínima total de 2.400 horas, tendo como referência uma carga horária anual de 800 horas, distribuídas em pelo menos 200 dias de efetivo trabalho escolar. (Brasil, 2013, p. 188)

Essa mudança também foi discutida pelos sujeitos nas mídias sociais:

Youtuber 21: Eu não entendi bem o que eles querem com esse negócio de aula em tempo integral. Eu estudo numa escola pública integral, temos dez aulas por dia e o que mais vejo é aluno dormindo na banca ou no meio da aula atualizando atividades do cursinho extra (porque passar no vestibular sem ter nenbuma aula de física ou biologia por exemplo é o cúmulo), tem aluno que trabalha também. A gente não tem tempo nem de respirar e ainda temos aulas precárias. Têm professor que passa semanas sem dar assunto novo. 
Youtuber 16: sou de Pernambuco, e a única coisa q realmente aconteceu foi a saturação dos alunos na escola, desgaste dos professores, péssimas condiçôes de escolas pra manter alunos presos das 7:30 as 17:00 hrs (Merenda ruim, falta de água, falta de recurso como piloto, data show, bebedouros, ventiladores entre outras coisas) que resulta em falta de tempo e interesse de todas as parte.

Observou-se que, entre aqueles que criticam esse ponto da reforma, certas limitações principalmente de natureza configuracional e organizacional decorrem desse aumento de carga horária. Uma delas diz respeito ao modo como se organizam as demais etapas de escolarização, pois o modelo de escola em tempo integral não é realidade de parcela significativa delas. Ou seja, como os sujeitos da escola se situam de modo comportamental e subjetivo frente a essa composição quando a mesma é apresentada somente nos últimos 3 dos 14 anos, aproximadamente, que envolvem a educação básica? Ainda, questionam-se as composições curriculares que serão empreendidas, pois é possível que haja aumento da sobreposição e repetição de conteúdos e das ações difundidas ao longo das demais fases escolares. Uma vez que, ampliar a carga horária do currículo não pode estar somente relacionada ao aumento de horas aula.

Esses indícios sociopolíticos se confirmam no destaque do vocábulo Governo, em um dos eixos centrais da Figura 6, pois reafirma a natureza e influência política no contexto educacional. Estrutura expressa de modo recorrente, nas narrativas analisadas, por vezes acompanhadas dos substantivos das ideologias tidas como de direita e esquerda ${ }^{9}$, cuja expressão tem sido destacada para uma aparente partidarização da escola brasileira, principalmente na figura dos professores que atuariam doutrinando os alunos para uma educação de esquerda. Esse também tem sido um dos argumentos do grupo que defende a "escola sem partido", movimento que tem se estruturado com base na narrativa de que há doutrinação político partidária, à esquerda no contexto das salas de aula. Todavia, não há dados ou pesquisas efetivadas a respeito que confirmem esses pressupostos.

Indícios podem ser capturados nos trechos a seguir.

Youtuber 27: Tiraram sociologia e flosofia da grade do ensino médio porque sabem que pessoas informadas e com senso crítico derrubam o estado.

Twitteiro 64: Bom dia meu amigo coxinha prof. de Educação Física. Vc n acreditou $q$ teria reforma d ensino médio e bateu palmas p golpe. Força ai parça.

8 Essa narrativa apresenta indícios de nascimento do Instituto de Corresponsabilidade pela Educação (ICE) que tem contribuído para a aproximação entre público-privado e mudanças estruturais no projeto de escolarização, como as escolas de tempo integral e configuração escolar com princípios empresariais de visão de mercado econômico.

9 Pode ser averiguado ao longo da leitura das composições textuais que os sujeitos que se consideram de direita assim se auto intitularam e partem da ideia da negação de direitos universais, e secundarizam argumentos de afirmação de ideologias liberais. Do outro lado, as pessoas que se consideram de esquerda, assim se assumem, porque defendem a ideia de um estado que oportunize políticas de igualdade e acesso. 
Youtuber 24: Não é sempre que falam sobre isso no Instituto federal em que eu estudo. As humanas como sociologia e flosofia falam mais sobre politica etc. Dizendo que não podemos deixar os politicos fazer tua cabeça etc, sempre olhar os dois lados da 'coisa' etc. Youtuber 26: Acha mesmo que a aula dada pelo estado de filosofia abrirá mentes críticas para derrubar o estado? É o estado quem dá a aula. Se ve quer ter senso crítico, passe um dia na internet vendo filosofia que vc aprenderá muito mais do que nas escolas estaduais que nem sequer têm professores capacitados para tal ato.

Por outro lado, para Certeau (2002), as ideologias políticas devem ser inseridas nas lógicas de um lugar que produz e reproduz militâncias que se organizam em torno de técnicas de fazer crer, estruturadas com base em um Belief, no qual reside um falar em nome de um real e a capacidade de discurso autorizado por um "real" que se entrecruzam com a narratividade da mídia - uma instituição do real - que colabora na organização de práticas, ou seja, em credibilidades políticas para um fazer crer.

Esse falar de um real pode ser averiguado nas disputas de narrativas realizadas nos ambientes de discussão das plataformas, marcadas por argumentos de antíteses entre projetos de escolarização que se coadunam para o formato de ensino médio e o tipo de conhecimento a ser compartilhado.

Algumas postagens tensionam o debate para um processo de mudança curricular iniciado ainda no Governo Dilma, discretamente expresso nas palavras de Dilma e Temer, presentes em uma das ramificações do eixo Reforma, sinalizado anteriormente na Figura 6.

Youtuber 22: Essa reforma já vinha sendo planejada pela Dilma, o Temer só deu a canetada. Existem coisas boas nessa iniciativa, como as aulas direcionadas ao curso que o aluno vai escolher na faculdade (Linguagens, Natureza, Humanas e Exatas), mas o principal que é retirar o Marxismo Cultural da grade e da metodologia de ensino das matérias, principalmente as Ciências Humanas que são completamente tendenciosas pra esquerda, ainda precisa ser feito.

Com isso, em vez de analisar os impactos da reforma, os argumentos são direcionados para a contradição do grupo que apoiou a então presidente e que agora critica essa mudança de mesmas bases; ou, para utilizar uma expressão própria dos usuários da internet: "o grupo da Dilma está de mimimi ou recalque..."

Outro ponto da questão política que as mídias analisadas apresentam refere-se às postagens como uma ferramenta de ilustração e propaganda do que está sendo realizado. Pode-se citar a postagem, com foto no Instagram e Facebook, de um senador da República que, em tempo real, participava das discussões na Comissão de Educação sobre a reforma, ou mesmo a presença do ministro da Educação no

10 "Mimimi" designaria, de modo pejorativo, a reclamação constante realizada por alguém ou por grupos de pessoas. Já recalque se refere ao desdenho ou forma de não valorizar uma determinada posição ou ação, simplesmente por ser contrário àquilo que a pessoa considera significativo. 
Senado Federal para acompanhar a votação na comissão mista, confirmando, assim, o uso das mídias sociais como ferramenta de interlocução. No caso, de proximidade e interação com o eleitorado desses representantes, mesmo que alguns possuam assessoria própria para isso.

A foto do senador foi acompanhada da seguinte legenda:

Senador da República no Instagram: \#ReformaEnsinoMedio Pessoal, está sendo instalada neste momento aqui no Senado a comissão mista que vai debater a Reforma do Ensino Médio. Gostaria de convidar vocês para contribuirem aqui nas redes com opiniöes sobre o assunto. Também vamos ouvir professores, pais e alunos capixabas para chegarmos a um novo Ensino Médio adequado às nossas necessidades. Conto com vocês!

A Figura 7 foi uma imagem postada no Instagram que sintetiza, de modo significativo, a polarização assumida sobre as questões políticas que envolvem a conjuntura brasileira, cujos desdobramentos estão expressos na reforma curricular do ensino médio.

Instagranzeiro 1: Essa charge é mais uma prova de que político e partido nunca pensaram no povo nem no país, e sim em seus projetos pessoais e de poder. Não importa quem criou, o que importa é se vai modernizar ou não a educação. Sem falar que o projeto ainda vai passar por uma longa discussão com especialistas. Não tem nada decidido, apenas um pequeno grupo já querendo tumultuar. Porque inclusive uma grande parte dos educadores apoiam essa iniciativa. Digo "INICIATIVA", ou seja, é apenas o início da discussão.

Outro argumento que emergira no teor das narrativas refere-se à fragilidade que envolve a realização de uma reforma por meio de medida provisória, e

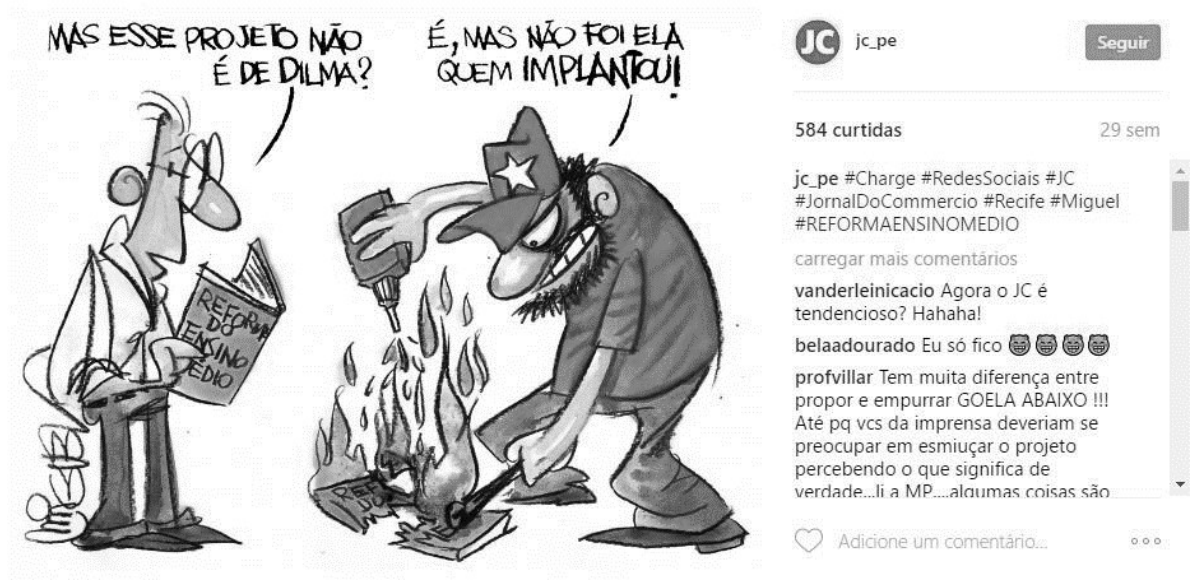

Fonte: extraída de Instagram.

Figura 7 - Como os discursos de direita e esquerda compreendem a reforma curricular do ensino médio. 
não como um projeto de lei, amplamente debatido, que enfrentou, como principal contra-argumento de defensores da reforma, o fato de que, por muitos anos se discute sobre o "fracasso" do ensino médio e nada ter sido realizado, de maneira consistente, por essas mesmas entidades, que agora criticam a reforma. É ressaltada também a articulação com a BNCC, que se desdobra para os itinerários de estudos e, consequentemente, a mudança na carga horária.

Instagranzeiro 2: Tem muita diferença entre propor e empurrar GOELA ABAIXO! Até $q$ vocs da imprensa deveriam se preocupar em esmiuçar o projeto percebendo o que significa de verdade... li a MP... algumas coisas são interessantes, mas na maior parte da coisa parece um projeto amador... deveriam ter vergonba de divulgar uma coisa sem pé nem cabę̧a....

Youtuber 30: Os professores foram ouvidos? Não Os alunos foram ouvidos? Não Os empresários? Com certeza.

O teor das narrativas somente fica mais bem elucidado quando inserido no momento histórico, social e político em que o Brasil se encontra. Dessa forma, é possível averiguar um contexto de bases políticas demarcado por narrativas e contranarrativas de natureza estética exemplificadas por concepções maniqueístas de direita e esquerda. Com isso, as discussões empreendidas pelas (re)apropriações dos sujeitos no lugar online concentram-se nos usos e consumos voltados às incoerências apresentadas por um determinado posicionamento do que uma análise mais ampliada sobre os desdobramentos dessa reforma.

Assim, as estratégias e táticas empreendidas por esses sujeitos concentram-se em um esforço de sinalização da contradição, da incipiência e da fragilidade do argumento disposto por um lado, mais do que o empreendimento de análises configuracionais e estruturais possíveis decorrentes dessa reforma. Pressupõe-se assim, que as modificações de bases sociopolíticas que têm tensionado o projeto de escolarização brasileiro oportunizam o desenvolvimento de práticas particulares em seus lugares de produção, que envolvam professores, alunos e pesquisador, em frente a esse contexto escolarizado que se reconfigura.

Para Han (2018) essas estruturas provenientes das práticas discursivas no ciberespaço sugerem um comportamento do tipo enxame e cardume construído a partir de um imaginário tencionado por algoritmos que indicam modos representativos que aproximam grupos e pessoas, em perspectivas e eixos em comum, que por sua vez incidem sobre comportamentos, posições e argumentos sobre elementos específicos. Com isso, em um primeiro momento as pessoas se conectam por fragmentos representativos de temáticas consensuais, subsequentemente conforme as discussões e argumentos são enunciados, há um processo de expansão, reorganização e direcionamentos uníssonos de aparentes verdades argumentativas, inflexíveis. $\mathrm{O}$ grupo, assim, produz barulho, forma um enxame, produzindo uma consonância de massa, com pouca ou nenhuma coerência, mas não desenvolve ação de massa, pela ausência de um nós. Personificando-se em homos eletronicus, ou aquele ser conectado cuja identidade foi dissolvida psiquicamente e o homo digitalis, indivíduo que mesmo em grupo mantem sua identidade e utiliza do virtual como espaço de reafirmação e de otimização de si mesmo e suas posições. 
Assim, é preciso situar as narrativas apresentadas sobre o ensino médio, destacando os sujeitos que as produziram nos modos de fazer e praticar o cotidiano dessa etapa, sem com isso desconsiderar as forças sociopolíticas que incidem sobre esse lugar. Em outras palavras, é preciso dar visibilidade às teias que estão envoltas no processo de constituição do cotidiano do ensino médio, na voz dos próprios sujeitos.

\section{OS ATORES SOCIAIS NO LUGAR ONLINE}

Cada uma das mídias sociais possui uma interface específica, para a qual um indivíduo deve criar uma conta ou perfil nessas plataformas. Após a realização desse procedimento, habilitam-se formas de interação, usos e consumos próprios entre os membros participantes. Para tanto, essas mídias desenvolvem ambientes específicos nos quais são produzidos discussões e comentários com base em um tema gerador originário da postagem de vídeos, imagens, textos ou dos três elementos articulados. Geralmente esse tema gerador é vinculado por um sujeito que detém certo nível de representação intragrupal.

Esses sujeitos são denominados digital influencers, pessoas que possuem e detêm certo nível de representação e podem influenciar gostos, interesses, opiniões e tendências perante um determinado grupo. Assim, foram identificados os primeiros sujeitos participantes do contexto das mídias analisadas e vale salientar que cada uma delas estabelece uma nomenclatura específica para apresentá-los.

O segundo grupo de indivíduos identificados é aquele que interage com a temática produzida. Em cada uma das mídias, existem ambientes específicos para essa finalidade. Assim, relativamente a determinados assuntos, os participantes discutem, emitem opiniões, divergem, brigam e concordam.

Verificou-se que os indivíduos que utilizam as redes sociais YouTube, Facebook e Instagram são, em sua maioria, jovens entre 15 e 24 anos, brancos, de classe média, homens, de médios e grandes centros urbanos. Para acessar essa informação foram consultados os perfis de todos os sujeitos da pesquisa com o objetivo de identificar a idade, a profissão e em alguns momentos outras fotos que os identificavam. No Twitter, em específico, são acrescidos a esse perfil políticos, principalmente deputados e senadores, que não estão nessa faixa etária, mas utilizam essas mídias como interlocutoras e veículos de propaganda de trabalho ao seu eleitorado. Todavia, é preciso salientar que esse procedimento não garante a veracidade dos perfis que estão no contexto da discussão, uma vez que a internet está permeada de contas fakes, para designar pessoas que criam perfis fictícios.

Assim, é possivel identificar que o acesso e uso das plataformas digitais é feito, prevalentemente, por jovens. Além disso, quando analisamos suas narrativas, percebemos que uma parcela significativa são alunos do ensino médio. Para Dayrell e Carrano (2002), as juventudes brasileiras, não devem ser compreendidas de modo reducionista, considerando os indicadores etários e biológicos, mas como categoria social que, ao mesmo tempo, é uma condição e um tipo de representação, sendo influenciadas por elementos econômicos, simbólicos, culturais e históricos.

Nesse sentido, as mudanças sociais transcorridas principalmente com o advento do digital em detrimento ao analógico têm contribuído para o desenvolvi- 
mento de uma geração de jovens que tem estabelecido diferentes relações de usos e consumos, inclusive por atravessamentos de subjetividade, com esse artefato cultural. A internet é parte do que é denominada de juventudes cyborgues $^{11}$, ou seja, as mídias e as tecnologias podem ser compreendidas como extensões de suas subjetividades.

Sales (2014), também fazendo uso do conceito de cyborgue, diz como o avanço das tecnologias da informática tem possibilitado outras maneiras de interação da juventude com os outros e seus contextos sociais, a ponto de afirmar que não se trata apenas de interação, e sim uma forma híbrida de ser e estar no mundo, em que máquina e organismo se confundem. Basta perceber como os smartphones têm se tornado um novo membro do corpo, uma espécie de artefato que atuaria como extensão das mãos e realizaria uma nova possibilidade de contato com o mundo, formando uma ecologia digital.

Ademais, as redes sociais acessadas por esses smartphones são/estão incorporadas ao cotidiano dos jovens, inclusive no dia-a-dia escolar, como formas de interação social, constituindo-se como sintaxes espaciais de um continuum entre o real e o virtual. Dessa forma, as postagens expressam elementos de subjetividade produzidos pelas experiências vividas nos cotidianos praticados, reatualizando uma das funções das redes sociais, a de permitir ao avatar autonomia e lugar de protagonismo, quanto a pontos de vistas, impressões, opiniões e demarcações das experiências sociais, que incidem nos sujeitos outra maneira existencial de ser, agora na condição cyborgue, ou seja, meio máquina, meio humano.

Ao mergulhar no teor das narrativas, é possível averiguar o modo particular como os atores compreendem a relação da tecnologia com a escolarização.

Youtuber 1: Eu super concordo com a opinião de vocês, estive envolvida nas ocupaçôes de escola, e era uma das pautas pela UBES, a tecnologia. Porém a nova reforma do EM não é nada, nada disso.

Youtuber 3: Exato! Os tempos são outros. E precisam de mudanças. E digo não só no ensino médio, como na graduação também. Precisamos de uma Linguagens mais contemporânea. Entender que as novas tecnologias vieram pra ajudar, que PRECISAM fazer parte do processo e que é tolo lutar contra isso, pq cada vez mais estão mais presente.

Youtuber 4: penso que essa questão de introduzir o mundo digital tenha $q$ ser algo moderado. Pq as primeiras ferramentas que conhecemos já veio acoplado no nosso sistema.

Twitteiro 1: O máximo de tecnologia que alguns professores usam na sala de aula éo DVD pra eles passarem algum filminho e pedir resumo depois.

Uma das questões mais difundidas pela reforma que explicam a recorrência do vocábulo aluno, tanto na Figura 5 quanto na Figura 6, refere-se ao lugar de destaque

11 Termo utilizado por Haraway (2000) para designar os seres humanos que vivem na fronteira entre máquina e organismo. Condição que produz seres cibernéticos e/ou biotecnológicos. 
que esse sujeito assumirá, pois ele cursará o ensino médio de modo unitário até o segundo ano, quando teria aproximadamente 16 anos. A partir dessa primeira fase, ele escolherá um dos itinerários apresentados pela reforma - linguagens, ciências da natureza, matemática, ciências humanas ou formação profissional - para cursar o ano e meio restante. As DCNs de 2013 já haviam sinalizado essa possibilidade de organização curricular por itinerários, "desde que garantida a simultaneidade das dimensões do trabalho, da ciência, da tecnologia e da cultura, e definidas pelo projeto político-pedagógico, atendendo necessidades, anseios e aspirações dos sujeitos e a realidade da escola e de seu meio" (Brasil, 2013, p. 189).

O item que envolve o protagonismo dos alunos na escolha de seus itinerários, também é discutido entre os sujeitos nas mídias sociais.

Twitteiro 3: A \#ReformadoEnsinoMedio na prática será a mutilação do currículo. A maioria não terá muitas opçóes perto de casa. O \#Enem será elitizado.

Twitteiro 4: E vc não pode escolher 2 áreas, ou personalizar a sua área: (\#reformadoensinomedio).

Twiiteiro 5: "escolbo o que saber e excluo o que não me serve" Esse aluno sabe que está se referindo a conhecimento de MUNDO? \#reformadoensinomedio vê bem!

Instagranzeiro 1: Ciências humanas serão optativas?????? Cadê o povo que sabe da história e clima do país agora????? Vao acabar!

Críticas que continuam a serem tecidas devido às dificuldades que os jovens teriam nos critérios de escolhas dessas áreas.

Twitteiro 6; Essa \#ReformaDoEnsinoMedio é a maior furada. Poucos jovens aos 15 anos sabem realmente o que quer como profissão.

Twitteiro 7: Se eu tivesse ficado com a área de conbecimento q eu queria qdo estava no Ensino Médio, estaria frustrada até hj. \#NovoEnsinoMédio.

Essas áreas estão descritas no seguinte trecho da LDB no 9.394/1996, com acréscimos da Lei no 13.415 de 2017:

Art. 36. O currículo do ensino médio será composto pela Base Nacional Comum Curricular e por itinerários formativos, que deverão ser organizados por meio da oferta de diferentes arranjos curriculares, conforme a relevância para $o$ contexto local e a possibilidade dos sistemas de ensino, a saber: I - linguagens e suas tecnologias; II - matemática e suas tecnologias; III - ciências da natureza e suas tecnologias; IV ciências humanas e sociais aplicadas. (Brasil, 2017b, p. 26)

De acordo com a legislação educacional brasileira, os aspectos caracterizantes e estruturantes serão realizados com a implantação da BNCC que se responsabilizará por definir as composições e organizações curriculares do ensino médio. Todavia, há de se salientar que, em 6 de abril de 2017, a terceira versão da BNCC foi aprovada, na qual estão apresentados os currículos para a educação infantil e o ensino fundamental. A parte destinada ao ensino médio foi apresentada em 3 de abril de 2018 (Brasil, 2017a). 
Os argumentos em defesa desse tipo de composição por áreas partem do pressuposto de que o jovem, ao escolher a de maior interesse e com ela os componentes curriculares que a compõem, estariam motivados a permanecerem na escola e, consequentemente, a aprenderem elementos que tenham maior identificação com ele, visto que a evasão agravada no ensino médio tem como uma de suas justificativas a pouca atratividade no tipo de conhecimento ensinado por essa etapa da educação básica. Assim, de modo simplório, há um fluxo de narrativas que considera e culpabiliza as fragilidades e limitações do ensino médio, em sua composição curricular organizado em torno de 13 componentes curriculares ${ }^{12}$ ofertados em 3 anos.

Aspectos que podem ser averiguados melhor conforme as transcrições a seguir:

Youtuber 5: Nao tiraram Ed. Física, só deram a oportunidade de gente q nao tá nem ai pra essa matéria, se focar melhor em outras. Mas vai continuar tendo.

Youtuber 7: Esse novo modelo na verdade já funciona em algumas escolas públicas no brasil, ao menos de forma parecida como nos IF (Institutos Federais). Eu tive a oportunidade de ter estudado no IFRN no modelo de técnico integrado ao ensino médio e não me arrependo.

Youtuber 8: Acho que deram essa opção para as escolas não? Porque se for assim eu vou bater palma de pé para essa matéria que nunca me foi útil).

Youtuber 9: Algumas pessoas acham que história, sociologia não são materiais que conscientizam os jovens sobre politica. Esse tipo de pessoa acredita em qualquer coisa que houve e, para eles, se você estuda história você vira esquerdista doutrinado, mas mal sabem eles que simplesmente não passam de infelizes alienados.

Uma das questões de menor consenso da reforma refere-se à quinta área de conhecimento, a de formação profissional, que retira a obrigatoriedade da licenciatura e flexibiliza a atuação docente com base no notório saber, assim descrito:

IV - profissionais com notório saber reconhecido pelos respectivos sistemas de ensino, para ministrar conteúdos de áreas afins à sua formação ou experiência profissional, atestados por titulação específica ou prática de ensino em unidades educacionais da rede pública ou privada ou das corporações privadas em que tenham atuado. (Brasil, 2017b, p. 2)

Sobre essa questão, registrou-se o seguinte comentário:

Facebookeiro 1: Sim, esse negócio de que se a pessoa tiver um "notório saber" é completamente inadequado! Eu, como estudante universitária de História Licenciatura fico muito preocupada quanto a isso. Eu ralei pra entrar na faculdade pra ser professora, ter meu diploma e nossa, agora qualquer pessoa pode dar aula? É só ter uma "noção" da matéria? Não está certo isso!

12 Sendo eles: Matemática, Física, Biologia, Química, Geografia, História, Filosofia, Sociologia, Língua Inglesa, Língua Portuguesa, Literatura, Artes e Educação Física. 
Outro sujeito que também ocupa lugar central nas discussões é o professor, cuja recorrência de vocábulo confirma o que pôde ser averiguado nas análises, uma vez que esse sujeito é tratado ora como herói, ora como vilão; ora como ator central, ora como sujeito secundário no projeto de escolarização brasileiro e do ensino médio.

Youtuber 10: Os professores fingem que ensinam e os alunos fingem que aprendem. O principal objetivo dos alunos é apenas passar, e não estão preocupados em aprender.

Youtuber 11: Qualquer aula ficaria muito boa se tivesse dois professores (menos monótono) e as pausas fossem cortadas como na edição. E também se a gente pudesse pausar pra entender um pedaço e não tivesse 28 malucos conversando no fundo.

Youtuber 12: Mas cara, a culpa também não é só da professora, pensa bem, professores recebem muito mal, não têm incentivo à felicidade, por isso ela é assim, se os professores fossem respeitados e bem pagos, sua professora ia ser menos rabugenta.

Youtuber 13: Ok, que o curriculo possa e deva ser melhorado. Mas, terá pouco efeito em escolas sucateadas e professores desvalorizados! Satisfeito isso, mais uma remuneração descente para os professores, já teríamos meia revolução no ensino.

Essa polifonia de narrativas e argumentações contribui para as discussões sobre as ressonâncias que essa reforma alcançará no projeto de escolarização brasileiro. Mesmo que de modo não consensual, elas expressam questionamentos significativos sobre o lugar do ensino médio no cerne da educação básica. Há também que se refletir até que medida as narrativas e contranarrativas pautadas em análises estéticas de natureza ideológicas representadas por direita e esquerda, sustentadas por elementos maniqueístas, têm acortinado maiores discussões sobre os impactos e reverberações de natureza estrutural, configuracional e de alcance que essas mudanças podem vir a produzir nos saberes/fazeres que envolvem o cotidiano dessa etapa da escolarização brasileira.

\section{CONSIDERAÇÕES FINAIS}

Por fim, conforme as questões anunciadas, é possível concluir que a reforma do ensino médio também esteve presente nas discussões realizadas nas mídias sociais analisadas, inicialmente, com base na MP no 746 e seu envio ao Congresso, e posteriormente como Lei $\mathrm{n}^{\circ} 13.415 / 17$. Os principais argumentos de quem defende essa reforma no ciberespaço assenta-se na representação associativa entre fracasso do ensino médio e o quantitativo disciplinar, tido como excessivo e que aparentemente contribuiria em quase nada para a vida social dos alunos. É possível dizer que, entre as mídias sociais analisadas, o YouTube se constituiu como principal fonte analítica, condição que se justifica pela quantidade de produção textual bem como pelas possibilidades interativas que essa mídia possibilita. Isso pode ser consequência de sua interface, na qual um vídeo é produzido e os demais membros têm um espaço para comentar aquele assunto.

É possível dizer ainda que as temáticas centrais abordadas em todas as mídias se referem a uma concepção de natureza política, na qual os argumen- 
tos que defendem as reformas o fazem com um sentimento de uma concepção liberal, tida como de direita, que seria mais coerente com os atuais interesses do mercado, ou seja, a escola deve compartilhar um tipo de conhecimento que possibilite a plena inserção no mercado de trabalho. Os argumentos contra essa reforma estão centrados em um viés, tido como de esquerda, no qual o Estado tem se afastado cada vez mais do compromisso de ofertar uma educação pública de qualidade que contribuiria para amenizar as desigualdades sociais na sociedade brasileira.

Com essa polarização, a discussão central deixa de ser o ensino médio e passa a ser as ideologias políticas, aspecto que faz dessa reforma uma expressão dessas questões. Porém, torna-se difícil o equacionamento dos impactos que essa reforma provocará no cotidiano dessa etapa da educação básica. Ainda assim, alguns pontos podem ser destacados com base nos comentários, por exemplo, os impactos que a BNCC realizará na qualidade de elemento estruturante do ensino médio.

Algumas questões se fazem pertinentes para serem sinalizadas: principalmente aquelas que se referem à estrutura e funcionamento de uma escola nesses moldes. Por exemplo: quais critérios seriam considerados quando os alunos fossem escolher o percurso a seguir? Imaginemos que 200 alunos de uma escola cheguem ao segundo ano para escolher o itinerário. Mas, se todos optarem por um único, a escola vai definir uma quantidade de vagas por itinerário? Ao fazer isso e o aluno não conseguir escolher a primeira opção por não possuir nota suficiente, não se incorre no risco de esse aluno evadir-se também? Com relação ao acesso ao ensino superior, as avaliações de ingresso apresentarão em sua organização apenas conhecimentos da área que o aluno optou por escolher? E, se o aluno optou por formação profissional e, ao final desse percurso, ele decidir ingressar no ensino superior, quais serão os critérios adotados?

\section{REFERÊNCIAS}

AGUIAR, S. Redes sociais na internet: desafios à pesquisa. In: Congresso Brasileiro de Ciências da Comunicação, 30., 2007, Santos. Anais... Santos, 2007.

$\mathrm{BLOCH}, \mathrm{M}$. Apologia da história ou o ofício do historiador. Rio de Janeiro: Jorge Zahar, 2001.

BRAGA, A. Técnica etnográfica aplicada à comunicação online: uma discussão metodológica. UNIrevista, São Leopoldo, v. 1, n. 3, p. 35-55, jul. 2006.

BRASIL. Parâmetros curriculares nacionais para o ensino médio: linguagens códigos e suas tecnologias. Brasília: MEC/SEB, 2000.

BRASIL. Diretrizes curriculares nacionais gerais para a educação básica. Brasília: MEC/CNE, 2013.

BRASIL. Base nacional comum curricular. Brasília: MEC/CNE, 2017a.

BRASIL. Lei no 9.394, de 20 de dezembro de 1996. Dispõe sobre a Lei de Diretrizes e Bases da Educação Nacional. Brasília: Senado Federal, Coordenação de Edições Técnicas, 2017b. 
CAMARGO, B. V.; JUSTO, A. M. Tutorial para o uso do software de análise textual IRAMUTEQ. Brasília: UFSC, 2013.

CERTEAU, M. de. A invenção do cotidiano: 1. artes do fazer. 15. ed. Petrópolis: Vozes, 2002.

DAYRELL, J.; CARRANO, P. Jovens no Brasil: difíceis travessias de fim de século e promessas de um outro mundo. 2002. (mimeo.).

FRIGOTTO, G. Concepções e mudanças no mundo do trabalho e o ensino médio. In: FRIGOTTO, G.; CIAVATTA, M.; RAMOS, M. (org.). Ensino médio integrado: concepção e contradições. São Paulo: Cortez, 2012. p. 57-82.

GINZBURG, C. Mitos, emblemas e sinais: morfologia e história. São Paulo: Companhia das Letras, 2002.

HAN, B.-C. No enxame: perspectivas do digital. Petrópolis: Vozes, 2018.

HARAWAY, D. J. Manifesto ciborgue: ciência, tecnologia e feminismo-socialista no final do século XX. In: SILVA, T. T. (org.). Antropologia do ciborgue: as vertigens do pós-humano. Belo Horizonte: Autêntica, 2000. p. 33-118.

KOZINETS, R. Netnografia: a arma secreta dos profissionais de marketing. 2010. Disponível em: http://kozinets.net/wp-content/uploads/2010/11/netnografia_ portugues.pdf. Acesso em: 15 nov. 2018.

KOZINETS, R. Netnografia: realizando pesquisa etnográfica online. Porto Alegre: Penso, 2014.

KRAWCZYK, N. O ensino médio no Brasil. São Paulo: Ação Educativa, 2009.

KUENZER, A.Z. O ensino médio agora é para a vida: entre o pretendido, o dito e o feito. Educação \& Sociedade, Campinas, v. 21, n. 70, p. 15-39, abr. 2000. https://doi. org/10.1590/S0101-73302000000100003

LEVY, P. Cibercultura. São Paulo: 34, 1999.

MONTARDO, S. P.; ROCHA, P.J. Cartografia da utilização da mídia no espaço virtual em Novo Hamburgo: proposta de referencial teórico. Gestão e Desenvolvimento, Novo Hamburgo, v. 2, n. 1, p. 63-73, 2005. https://doi.org/10.25112/rgd.v2i1.1066

MOREIRA, A. F. B. Propostas curriculares alternativas: limites e avanços. Educação \& Sociedade, Campinas, ano 21, n. 73, p. 109-138, dez.2000. https://doi.org/10.1590/ S0101-73302000000400009

POISSANT, L. A passagem do material para a interface. In: DOMINGUES, D. (org.). Arte, ciência e tecnologia: passado, presente e desafios. São Paulo: Editora Unesp, 2009. REDAÇÃO. O que é hashtag. Canal Tech, 2016. Disponível em: www.canaltech.com. br/produtos/o-que-e-hashtag/. Acesso em: 10 jun. 2019.

RIBEIRO, C. Conheça as redes sociais mais usada no Brasil e no mundo em 2018. TechTudo, 2019. Disponível em: https://www.techtudo.com.br/noticias/2019/02/ conheca-as-redes-sociais-mais-usadas-no-brasil-e-no-mundo-em-2018.ghtml. Acesso em: 10 jun. 2019.

SACRISTÁN, G. O currículo: uma reflexão sobre a prática. Porto Alegre: Artmed, 2000. 
SALES, S. Tecnologias digitais e juventude ciborgue: alguns desafios para o currículo do ensino médio. In: DAYRELL, J.; CARRANO, P.; MAIA, C. L. (org.). Juventude e ensino médio: sujeitos e currículos em diálogo. Belo Horizonte: UFMG, 2014. p. 229-248.

\section{SOBRE OS AUTORES}

Murilo Eduardo Nazário é doutor em educação física pela Universidade Federal do Espírito Santo (UFES). Professor da Universidade de Vila Velha (UVV).

E-mail: murilo_nazario@hotmail.com

Wagner Dos Santos é doutor em educação pela Universidade Federal do Espírito Santo (UFES). Professor da mesma instituição.

E-mail: wagnercefd@gmail.com

Amarílio Ferreira Neto é doutor em educação pela Universidade Metodista de Piracicaba (Unimep). Professor da Universidade Federal do Espírito Santo (UFES).

E-mail: amariliovix@gmail.com

Conflitos de interesse: Não há conflito de interesse.

Financiamento: Não houve fonte de financiamento.

Contribuições dos autores: Administração do Projeto: Ferreira Neto, A. Análise Formal, Conceituação, Curadoria de Dados, Metodologia, Escrita - Revisão e Edição: Nazário, M.E.; Santos, W.; Ferreira Neto, A. Investigação, Escrita - Primeira Redação: Nazário, M.E. Supervisão, Validação e Visualização: Ferreira Neto, A.; Santos, W. 